\title{
ECOLOGICAL ANALYSIS OF SELECTED STAGES OF THE FOOD PACKAGING PRODUCTION PROCESS
}

doi: $10.2478 /$ czoto-2021-0016

Date of submission of the article to the Editor: 29/11/2020

Date of acceptance of the article by the Editor: 27/03/2021

Patrycja Bałdowska-Witos ${ }^{1}$ - orcid id: 0000-0003-0547-4400

Adam Idzikowski ${ }^{2}$ - orcid id: 0000-0003-1178-8721

1 University of Science and Technology in Bydgoszcz, Poland

${ }^{2}$ Czestochowa University of Technology, Poland

\begin{abstract}
Eco-efficiency is a new concept of environmental analysis seeking to improve products, processes and manufacturing materials. The eco-efficiency analysis gives the opportunity to find the most effective solution with the lowest environmental burden in the bottle forming process. For this purpose, the LCA (Life Cycle Assessment) technique of environmental management was used to evaluate selected stages of the bottle forming process. The analysis was carried out using the Eco Indicator 99 method using the SimaPro software.
\end{abstract}

Keywords: Eco-Indicator 99, Life Cycle Assessment, The Mixing Triangle, environmental management

\section{INTRODUCTION}

Eco-efficiency is a new concept of environmental analysis seeking to improve products, processes and manufacturing materials. The eco-efficiency analysis gives the opportunity to find the most effective solution (Kruszelnicka et al., 2020), bringing the greatest benefits, while at the same time having the lowest environmental burden in the bottle forming process. Many companies operating in global markets use the standardized Life Cycle Assessment (LCA) method, conduct research in terms of technical and material solutions, thus demonstrating the lowest environmental impact (Wilczarska, 2012). By using the LCA method, enterprises declare limiting their environmental impact to a greater extent than the competition, and the results of the assessment shape new production directions. In the current time of the COVID-19 pandemic, plastics have become a serious threat to natural ecosystems and human health, and the forecasts developed so far predict a twofold increase in the amount of plastic waste by 2030 . However, the assumed forecasts probably worsen due to the excessive use of polymers in the production of personal protective equipment and disposable packaging. Such activities can cause negative environmental impacts, including global warming, carbon footprint, acidification, ozone formation, and eutrophication. The aim of the study is to determine the environmental impacts arising at the stage of evaluation of selected technological operations in the process of 
forming bottles made of polyethylene terephthalate and polylactide. The analysis included the assessment of environmental impacts for selected six technological operations of the bottle forming process. The results of the analysis were presented at the endpoint characterization stage and at the weighing stage using the triangle of weighting factors.

\section{METHODOLOGY OF RESEARCH}

The first step of the LCA is to define the purpose and scope of the analysis (Fuc et al., 2016), which can be established from the analysis and understanding of the product life cycle (Jian et al., 2020). For this purpose, the technological process of forming bottles made of PET and PLA in Poland was assessed. This process can be decomposed into six unit operations while taking into account the demand for media and materials (Klimecka-Tatar, 2017; Kojnoková et al., 2020; Rosak-Szyrocka and Abbase, 2020). The functional unit of the study was 1000 bottles with a capacity of 1 I (Bałdowska-Witos et al., 2020). The scope of the analysis included taking the preforms into the oven, heating them in an infrared oven, stretching and elongation, as well as pressure forming the preform, degassing and cooling the finished bottle. The area of analysis was defined by the boundaries of the adopted system. The same production sites are assumed, but different, although very similar production methods are presented, as a consequence of which PET and PLA bottles with different parameters are produced (Bałdowska-Witos et al., 2019). All exclusions and limitations were made simultaneously for both analyzed systems. The analysis included six indicated technological operations relating to the collection of preforms, their transfer to the heating furnace, heating and pressure forming of the preforms, degassing and cooling the finished bottles. As a result, the technological operations of the adopted processes were burdened with the same simplifications, which allowed to assume the level of exclusion below $0.01 \%$ of the share in the entire life cycle and share in all potential environmental impacts for each of the considered technological operations for both types of PET and PLA bottles. The functional unit adopted for the research was determined on the basis of data collected from the manufacturing company. It determines the production of 1,000 bottles of 1 liter capacity.

Studying the impact of the life cycle of the process of forming beverage bottles is to enable the understanding and evaluation of data for potential environmental impacts. The LCIA consists of elements such as the selection of the appropriate impact category, indicators of this category and characterization models (Baldowska-Witos et al., 2021) (Kuczewnski et al., 2011). The voluntary elements include standardization, grouping, weighting and data quality analysis. In the system adopted for analyzes, the Eco-Indicator 99 method was selected (Shen et al., 2010) (Bałdowska-Witos et al., 2019).

The Eco-indicator 99 method is based on modelling the environmental impact at the environmental mechanism endpoint level (Madival et al., 2009) (Ullah et al., 2016). All standard impact categories are included in the analysis using this model: carcinogens, resp. organics, resp. inorganics, climate change, radiation, ozone layer, ecotoxicity, acidification/eutrophication, land use, minerals and fossil fuels. Their selection was consistent with the purpose and scope of the research (Piasecka et al., 2019). These impact categories can be grouped into three larger groups, defined as areas of influence: human health, ecosystem quality, resources. In the case of human health, the DALY (Disability Adjusted Life-Years) unit is used, and as a category indicator - 
YLL (Years of Life Lost) and YLD (Years Lived Disabled) units. DALY is an internationally recognised unit, used by the WHO and the World Bank to evaluate health statistics. Within its framework, various diseases are assigned weights from 0 (ideal health) to 1 (death). The DALY unit expresses six impact categories: carcinogens, resp. organics, resp. inorganics, climate change, radiation and ozone layer. The ecosystem quality unit is PAF (Potentially Affrcted Fraction) or PDF (Potentially Dissapeared Fraction) (Doerffer K., et al., 2021). The three impact categories assessed in this area (ecotoxicity, acidification/eutrophication, land use) selected representative species groups. For ecotoxicity (PAF-m2/yr), these were lower terrestrial and aquatic animal species, while acidification/eutrophication and land use (PDF-m2/yr) were referred to selected vascular plant species. It is also possible to convert the PAF unit to PDF (Lewandowska, 2011) (Czaplicka-Kolarz et al., 2013).

\section{RESULTS}

The result of the simulation studies was to determine the level of potential impacts of six technological operations of forming PET and PLA beverage bottles on three impact categories: human health, quality of ecosystems and resource depletion. The results of the research to assess the potential impacts of technological operations for the PET bottle are presented in (Table 1). The highest levels of environmental impact of a PET bottle were observed for the ecosystem quality category, for which as many as four technological operations: pre-heating preform, heated preform, stretched and elongated preform and pressure-formed preform showed the highest potential environmental damage. Relatively similar results were obtained for the process of forming a PLA bottle, for which three technological operations negatively affecting the ecosystem were recorded in as many as two categories of impact (human health, quality of ecosystems) (Table 2).

Table 1

Influence of damage categories on PET bottle forming operations

\begin{tabular}{|l|l|l|c|c|c|c|}
\hline $\begin{array}{l}\text { Impact } \\
\text { category }\end{array}$ & $\begin{array}{l}\text { Preform } \\
\text { before } \\
\text { heating }\end{array}$ & $\begin{array}{c}\text { Heated } \\
\text { performa }\end{array}$ & $\begin{array}{c}\text { Stretched } \\
\text { and } \\
\text { elongated } \\
\text { performa }\end{array}$ & $\begin{array}{c}\text { Pressure- } \\
\text { molded } \\
\text { preform }\end{array}$ & $\begin{array}{c}\text { Degassing } \\
\text { the formed } \\
\text { bottle }\end{array}$ & $\begin{array}{c}\text { Cooling the } \\
\text { formed } \\
\text { bottle }\end{array}$ \\
\hline $\begin{array}{l}\text { Human } \\
\text { health,\% }\end{array}$ & $\underline{76,31278}$ & $\underline{8,853106}$ & $\underline{5,725587}$ & 4,553229 & 0,732106 & 3,823194 \\
\hline $\begin{array}{l}\text { Ecosystem } \\
\text { quality, \% }\end{array}$ & $\underline{71,28977}$ & $\underline{9,474228}$ & $\underline{6,127585}$ & $\underline{4,872532}$ & 0,783529 & 7,452359 \\
\hline $\begin{array}{l}\text { Resouces, } \\
\%\end{array}$ & $\underline{97,27423}$ & 1,020974 & 0,73758 & 0,507762 & 0,094304 & 0,365152 \\
\hline & $\begin{array}{l}\text { Technological operations representing } 90 \% \text { of the sum of the significance of } \\
\text { the analyzed results }\end{array}$ \\
\hline
\end{tabular}

Table 2

Influence of damage categories on PLA bottle forming operations

\begin{tabular}{|l|c|c|c|c|c|c|}
\hline $\begin{array}{l}\text { Impact } \\
\text { category }\end{array}$ & $\begin{array}{c}\text { Preform } \\
\text { before } \\
\text { heating }\end{array}$ & $\begin{array}{c}\text { Heated } \\
\text { performa }\end{array}$ & $\begin{array}{c}\text { Stretched } \\
\text { and } \\
\text { elongated } \\
\text { performa }\end{array}$ & $\begin{array}{c}\text { Pressure- } \\
\text { molded } \\
\text { preform }\end{array}$ & $\begin{array}{c}\text { Degassing } \\
\text { the formed } \\
\text { bottle }\end{array}$ & $\begin{array}{c}\text { Cooling } \\
\text { the formed } \\
\text { bottle }\end{array}$ \\
\hline
\end{tabular}




\begin{tabular}{|l|c|c|c|c|c|c|}
\hline $\begin{array}{l}\text { Human } \\
\text { health,\% }\end{array}$ & $\underline{77,16132}$ & $\underline{7,722125}$ & $\underline{5,928199}$ & 4,787518 & 0,809239 & 3,591598 \\
\hline $\begin{array}{l}\text { Ecosystem } \\
\text { quality, \% }\end{array}$ & $\underline{80,71111}$ & $\underline{5,809433}$ & $\underline{4,475387}$ & 3,602079 & 0,610927 & 4,79106 \\
\hline $\begin{array}{l}\text { Resouces, } \\
\%\end{array}$ & $93, \underline{05906}$ & 1,891509 & 2,413238 & 1,197726 & 0,329414 & 1,109051 \\
\hline & $\begin{array}{l}\text { Technological operations representing } 90 \% \text { of the sum of the significance of } \\
\text { the analyzed results }\end{array}$ \\
\hline
\end{tabular}

In order to further estimate the potential environmental damage, the obtained data was compared separately for each of the impact categories. In the case of the human health category, a higher level of impact of technological operations of the PLA bottle molding process was observed (Table 3 ). In line with the results evaluation technique adopted in LCA, the processes for which the sum of the test results is $90 \%$ are considered significant. In the analyzed case, it can be concluded that the essence of the analysis is limited to the first three technological operations for which the levels of interactions are, for the preform before heating 2.44E-07 DALY (approx. 77\%), the heated preform $2.44 \mathrm{E}-08$ DALY $(7.7 \%)$ and the stretched and elongated preforms 1.88E-08 DALY (approx. 5.9\%).

Table 3

Influence of the PET and PLA bottle forming process on the human health category, DALY

\begin{tabular}{|l|c|l|c|c|c|c|}
\hline Preform & $\begin{array}{c}\text { Preform } \\
\text { before } \\
\text { heating }\end{array}$ & $\begin{array}{c}\text { Heated } \\
\text { perform }\end{array}$ & $\begin{array}{c}\text { Stretched } \\
\text { and } \\
\text { elongated } \\
\text { perform }\end{array}$ & $\begin{array}{c}\text { Pressure- } \\
\text { molded } \\
\text { preform }\end{array}$ & $\begin{array}{c}\text { Degassing } \\
\text { the formed } \\
\text { bottle }\end{array}$ & $\begin{array}{c}\text { Cooling the } \\
\text { formed } \\
\text { bottle }\end{array}$ \\
\hline PLA & $2,44 \mathrm{E}-07$ & $2,44 \mathrm{E}-08$ & $1,88 \mathrm{E}-08$ & $1,52 \mathrm{E}-08$ & $2,56 \mathrm{E}-09$ & $1,14 \mathrm{E}-08$ \\
\hline PET & $2,11 \mathrm{E}-07$ & $2,45 \mathrm{E}-08$ & $1,58 \mathrm{E}-08$ & $1,26 \mathrm{E}-08$ & $2,02 \mathrm{E}-09$ & $1,06 \mathrm{E}-08$ \\
\hline
\end{tabular}

When assessing the significance of the analyzed technological operations in the case of forming a PET bottle, the first three operations were considered to be $90 \%$ of all receipts. In the vast majority of cases responsible for the level of impact on human health were the electricity and polyethylene terephthalate (Table 4). Relatively other results were obtained for the PLA bottle molding process. The electricity used was responsible for the vast majority of negative impacts on human health. Polylactide as a raw material used in the production process reflects the positive environmental benefit when heating the preforms in the infrared oven -1.4680127 DALY (Table 5).

Table 4

The levels of impacts on human health input in the process of bottle PET

\begin{tabular}{|l|c|c|c|}
\hline Criterion & $\begin{array}{c}\text { Preform } \\
\text { before } \\
\text { heating }\end{array}$ & $\begin{array}{c}\text { Heated } \\
\text { perform }\end{array}$ & $\begin{array}{c}\text { Stretched } \\
\text { and } \\
\text { elongated } \\
\text { perform }\end{array}$ \\
\hline The sum of all processes, $\%$ & 100 & 100 & 100 \\
\hline Compressed air, $\mathrm{kPa}$ & 0 & 0 & 0,00904414 \\
\hline Electricity, medium voltage $\{\mathrm{PL}\}$ & 0,537235598 & 100,8876914 & 99,99095586 \\
\hline Polyethylene terephthalate & 99,4627644 & 0,887691437 & 0 \\
\hline
\end{tabular}


Table 5

The levels of impacts on human health input in the process of PLA bottles

\begin{tabular}{|l|c|c|c|}
\hline Criterion & $\begin{array}{c}\text { Preform } \\
\text { before } \\
\text { heating }\end{array}$ & $\begin{array}{c}\text { Heated } \\
\text { perform }\end{array}$ & $\begin{array}{c}\text { Stretched } \\
\text { and } \\
\text { elongated } \\
\text { perform }\end{array}$ \\
\hline The sum of all processes,\% & 100 & 100 & 100 \\
\hline Compressed air, kPa & 0 & 0 & 0,003431392 \\
\hline Electricity, medium voltage $\{\mathrm{PL}\}$ & 100 & 101,46801 & 99,99655364 \\
\hline Polylactide & 0 & $-1,4680127$ & 0 \\
\hline
\end{tabular}

As a result of the simulation studies, the size of environmental damage constituting a nuisance to the quality of the ecosystem was estimated (Table 6). The highest negative impact level was observed for the PLA bottle forming process. The highest impact, $>80 \%$, was recorded for the operation of the PLA preform before heat. Among all the analyzed technological operations affecting the category of ecosystem quality in the process of forming a PET bottle, four were distinguished: pre-heat preform, heated preform, stretched and elongated preform, pressure-formed preform, which showed a potential negative impact on the quality of ecosystems.

Table 6

Influence of the PET and PLA bottle molding process on the ecosystem quality category

\begin{tabular}{|l|c|c|c|c|c|c|}
\hline Preform & $\begin{array}{c}\text { Preform } \\
\text { before } \\
\text { heating }\end{array}$ & $\begin{array}{c}\text { Heated } \\
\text { perform }\end{array}$ & $\begin{array}{c}\text { Stretched } \\
\text { and } \\
\text { elongated } \\
\text { perform }\end{array}$ & $\begin{array}{c}\text { Pressure- } \\
\text { molded } \\
\text { preform }\end{array}$ & $\begin{array}{c}\text { Degassing } \\
\text { the formed } \\
\text { bottle }\end{array}$ & $\begin{array}{c}\text { Cooling the } \\
\text { formed bottle }\end{array}$ \\
\hline PLA & $8,70 \mathrm{E}-10$ & $6,26 \mathrm{E}-11$ & $4,82 \mathrm{E}-11$ & $3,88 \mathrm{E}-11$ & $6,58 \mathrm{E}-12$ & $5,16 \mathrm{E}-11$ \\
\hline PET & $4,73 \mathrm{E}-10$ & $6,29 \mathrm{E}-11$ & $4,06 \mathrm{E}-11$ & $3,23 \mathrm{E}-11$ & $5,20 \mathrm{E}-12$ & $4,94 \mathrm{E}-11$ \\
\hline
\end{tabular}

Analyzing the data input responsible for any injury leading to a reduction in the quality of the ecosystem, it should be noted that in two cases used polyethylene terephthalate showed environmental benefit. Potentially, the highest negative impact level corresponded to the electricity used in the production process (Table 7).

\section{Table 7}

Levels of impact on the quality of the input data ecosystem in the process of creating a PET bottle

\begin{tabular}{|l|c|c|c|c|}
\hline Criterion & $\begin{array}{c}\text { Preform } \\
\text { before } \\
\text { heating }\end{array}$ & $\begin{array}{c}\text { Heated } \\
\text { perform }\end{array}$ & $\begin{array}{c}\text { Stretched } \\
\text { and } \\
\text { elongated } \\
\text { perform }\end{array}$ & $\begin{array}{c}\text { Pressure- } \\
\text { molded } \\
\text { preform }\end{array}$ \\
\hline The sum of all processes, \% & 100 & 100 & 100 & 100 \\
\hline Compressed air, $\mathrm{kPa}$ & 0 & 0 & $\begin{array}{c}0,0063165 \\
06\end{array}$ & 0 \\
\hline Electricity, medium voltage $\{\mathrm{PL}\}$ & 0,6154829 & 100,89535 & 99,993683 & 49 \\
\hline Polyethylene terephthalate & 56 & 94 & 0 & $-1,1482867$ \\
\hline
\end{tabular}


In the case of the analysis of the PLA bottle forming process, the raw material polylactide -1.8227594 species.yr used in the bottle forming process showed the greatest environmental benefit (Table 8).

Table 8

Levels of impact on the quality of the input data ecosystem in the process of creating a PLA bottle

\begin{tabular}{|l|c|c|c|}
\hline Criterion & $\begin{array}{c}\text { Preform } \\
\text { before } \\
\text { heating }\end{array}$ & $\begin{array}{c}\text { Heated } \\
\text { perform }\end{array}$ & $\begin{array}{c}\text { Stretched and } \\
\text { elongated perform }\end{array}$ \\
\hline The sum of all processes, \% & 100 & 100 & 100 \\
\hline Compressed air, $\mathrm{kPa}$ & 0 & 0 & 0,002319805 \\
\hline Electricity, medium voltage $\{\mathrm{PL}\}$ & 100 & 101,82276 & 99,99766968 \\
\hline Polylactide & 0 & $-1,8227594$ & 0 \\
\hline
\end{tabular}

Table 9

Influence of the PET and PLA bottle forming process on the resource depletion category

\begin{tabular}{|l|l|l|l|l|l|l|}
\hline Preform & $\begin{array}{l}\text { Preform } \\
\text { before } \\
\text { heating }\end{array}$ & $\begin{array}{l}\text { Heated } \\
\text { perform }\end{array}$ & $\begin{array}{l}\text { Stretched } \\
\text { and } \\
\text { elongated } \\
\text { perform }\end{array}$ & $\begin{array}{l}\text { Pressure- } \\
\text { molded } \\
\text { preform }\end{array}$ & $\begin{array}{l}\text { Degassing } \\
\text { the formed } \\
\text { bottle }\end{array}$ & $\begin{array}{l}\text { Cooling the } \\
\text { formed } \\
\text { bottle }\end{array}$ \\
\hline PLA & 0,006721 & 0,000137 & 0,000174 & $8,65 \mathrm{E}-05$ & $2,38 \mathrm{E}-05$ & $8,01 \mathrm{E}-05$ \\
\hline PET & 0,0193801 & 0,0002034 & 0,0001469 & 0,0001012 & $1,88 \mathrm{E}-05$ & $7,27 \mathrm{E}-05$ \\
\hline
\end{tabular}

The results of the analysis for the resource depletion category in both analyzed cases referred to the first technological operation: preforms before heating. A significantly higher level of impact on the resource depletion category was observed for the PLA bottle molding process, reaching the value of 0.006721 USD2013 (Table 9). When comparing the technological operations of PET and PLA bottles, it was found that polyethylene terephthalate has the greatest potential impact on resource depletion (Table 10). Relatively different values were obtained for the operation of the PET preform before heating, in the process in which electricity shows the greatest environmental damage (Table 11).

Table 10

Levels of impact on the depletion of input data resources in the process of creating a PET bottle

\begin{tabular}{|l|c|}
\hline Criterion & Preform before heating \\
\hline The sum of all processes, $\%$ & 100 \\
\hline Compressed air, $\mathrm{kPa}$ & 0 \\
\hline Electricity, medium voltage $\{\mathrm{PL}\}$ & 0,054289786 \\
\hline Polyethylene terephthalate & 99,94571021 \\
\hline
\end{tabular}


Table 11

Levels of impact on the depletion of input data resources in the process of creating a PLA bottle

\begin{tabular}{|l|c|}
\hline Criterion & $\begin{array}{c}\text { Preform } \\
\text { before heating }\end{array}$ \\
\hline The sum of all processes, \% & 100 \\
\hline Compressed air, kPa & 0 \\
\hline Electricity, medium voltage $\{\mathrm{PL}\}$ & 100 \\
\hline Polylactide & 0 \\
\hline
\end{tabular}

Weighting consists in determining and assigning a degree of importance (weighting factor) to individual impact categories and multiplying by them the normalized results of the index. Carrying out the weighting process allows obtaining results in environmental points $(\mathrm{Pt})$. A thousand environmental points are equal to the environmental impact of one European in one year.

Table 12

The results of the impacts damage categories

\begin{tabular}{|c|c|c|c|c|c|}
\hline Damage category & Unit & $\begin{array}{c}\text { PLA } \\
\text { preforms } \\
\text { heating }\end{array}$ & $\begin{array}{c}\text { PET } \\
\text { preforms } \\
\text { heating }\end{array}$ & $\begin{array}{c}\text { Stretching } \\
\text { and } \\
\text { elongation } \\
\text { of the PLA } \\
\text { preform }\end{array}$ & $\begin{array}{c}\text { Stretching } \\
\text { and } \\
\text { elongation } \\
\text { of the PET } \\
\text { preform }\end{array}$ \\
\hline Ecosystem quality & $\mathrm{Pt}$ & 0,002277 & 0,000345 & 0,001649 & 0,002312 \\
\hline Resources & $\mathrm{Pt}$ & 0,000882 & 0,004706 & 0,001096 & 0,001305 \\
\hline Human Health & $\mathrm{Pt}$ & 0,001921 & 0,007886 & 0,000968 & 0,001393 \\
\hline
\end{tabular}

When making a comparative analysis of environmental loads, it should be stated that a bottle made of non-biodegradable plastic causes twice as much environmental damage, taking into account the negative impacts on the quality of the ecosystem, climate change, depletion of raw materials and human health. The results of environmental damage loads for the process of stretching and elongation of preforms made of PET and PLA are presented in Table 12. The result of the comparative analyzes is the statement about comparable environmental loads as a result of the stretching and heating process of the analyzed preforms. For this purpose, a graphic interpretation of the triangle of weighting factors was used. Figure 1 shows the levels of environmental impacts for the preform heating process. In terms of these interactions, the dominance of the PLA preform heating stage over the PET preform heating stage. This is related to the acquisition of energy resources from nonrenewable sources. Environmental impacts are mainly related to the acquisition of raw materials for the production of fuels, mainly hard coal, which is the basis of the energy system in Poland.

From the weight triangle, we can conclude that a PET preform has a lower impact on human health than a PLA preform if a high weight (33\%) is given to resources, while a weight $(>78 \%)$ is attributed to the environment. Otherwise the opposite is true. Figure 2 shows the levels of environmental impacts at the stage of stretching and lengthening the hot preform, in percentage terms, which clearly shows that the 
biodegradable material used in the landfill is potentially more environmental damage in the three analyzed areas.

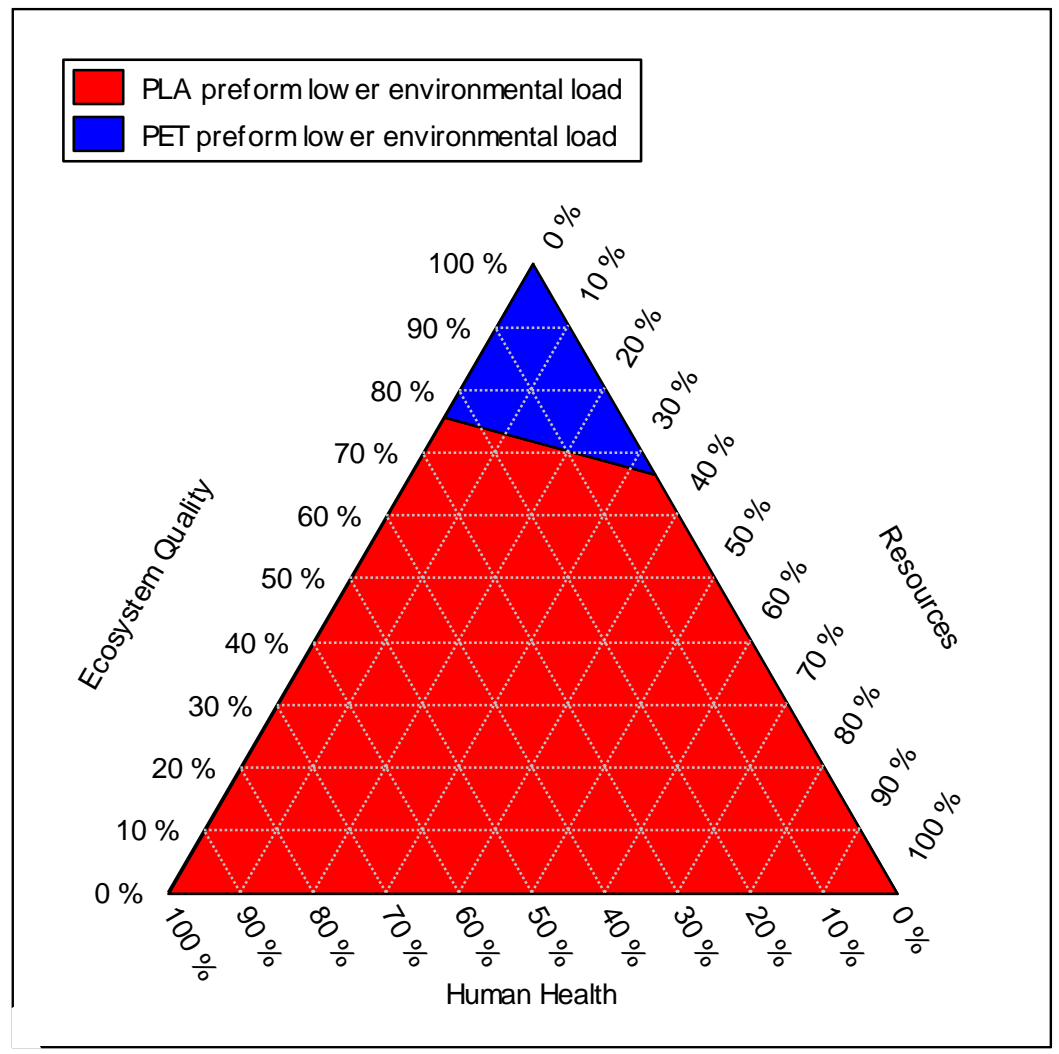

Fig. 1. Weighting triangle showing the line of indifference and sub-areas with their specific ranking orders

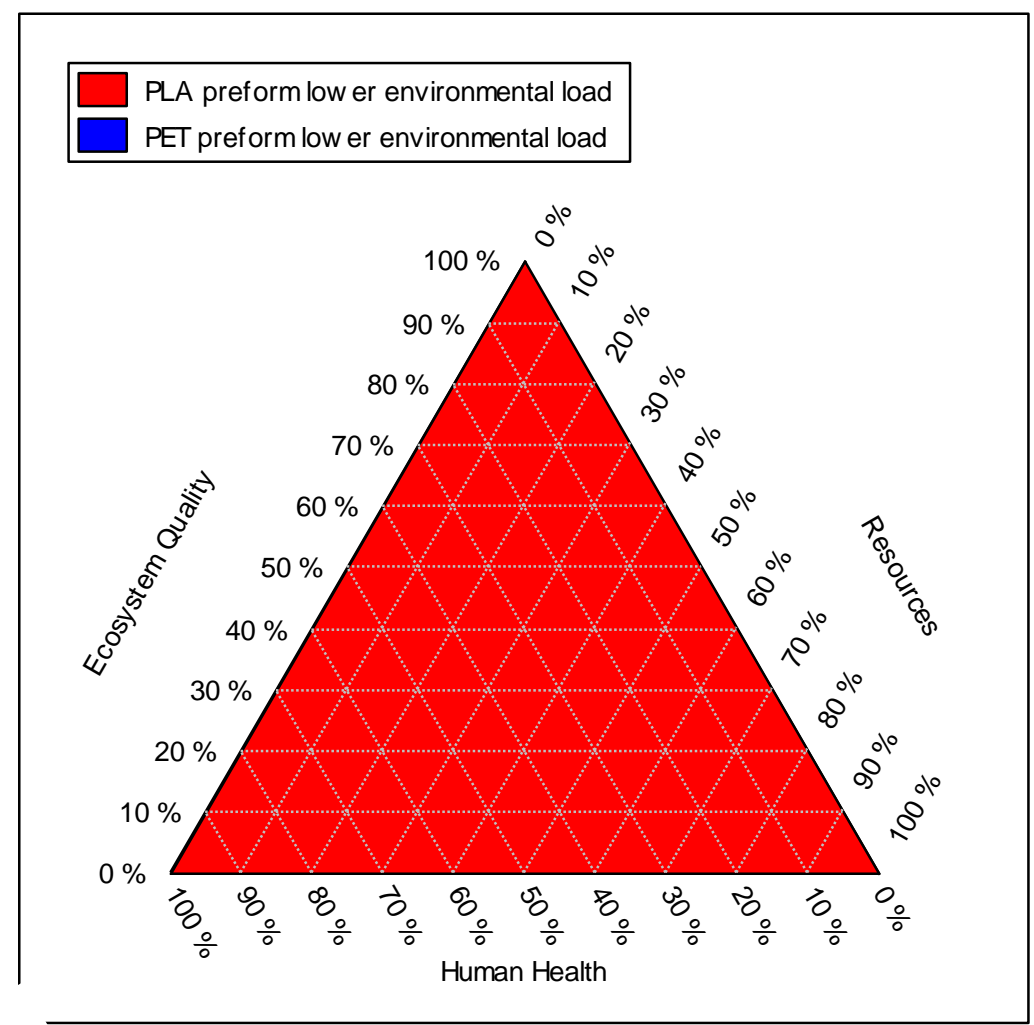

Fig. 2. Weighting triangle showing the line of indifference and sub-areas with their specific ranking orders 


\section{CONCLUSION}

The technological processes taking place in the beverage bottle blow molding machine, in particular related to the eco-efficiency of packaging forming processes, occur with the occurrence of strictly defined activities and related variables of unit electricity consumption, mass efficiency, power demand or the influence of the raw material used, are complex and difficult to direct interpretation. Based on the experiment, it was determined that the share of electricity demand is greater in the process of forming PLA bottles. The result of the conducted experiment of evaluation of selected phases of the production cycle of forming PET and PLA bottles for beverages is the determination of quantitative environmental consequences. As a result of the conducted considerations, it can be concluded that in the preform collection process, raw materials made of PLA plastic had the greatest impact at the level of $77 \%$. The share of raw material in the bottle forming process depends on the primary sourcing, processing, production, use and management processes. In the case of the human health category, a higher level of technological operations impact of the PLA bottle molding process was observed. As a result of the conducted simulation studies, the size of environmental damage constituting a nuisance to the quality of the ecosystem was estimated. The highest negative impact level was observed for the PLA bottle forming process. The highest impact of $>80 \%$ was recorded for the operation of the PLA preform before heat. A significantly higher level of impact on the resource depletion category was observed for the PET bottle molding process.

\section{REFERENCES}

Bałdowska-Witos, P., Doerffer, K., Pysz, M., Doerffer, P., Tomporowski, A., Opielak, M., 2021. Manufacturing and Recycling Impact on Environmental Life Cycle Assessment of Innovative Wind Power Plant Part 2/2, Materials, 14, 204.

Bałdowska-Witos, P., Kruszelnicka W., Kasner R., Tomporowski A., Flizikowski J., Mroziński A., 2019. Wpływ produkcji butelek z tworzyw sztucznych na środowisko naturalne. Cz. II. Analiza niepewności danych w ocenie cyklu życia polimerowych butelek do napojów z PET i PLA z wykorzystaniem techniki Monte Carlo, Przem. Chem., 1(10), 166-170.

Bałdowska-Witos, P., Kruszelnicka, W., Kasner, R., Rudnicki, J., Tomporowski, A., Flizikowski, J., 2019. Wpływ produkcji butelek z tworzyw sztucznych na środowisko naturalne. Cz. I. Zastosowanie metody oceny ReCiPe 2016 w celu identyfikacji problemów środowiskowych, Przem. Chem., 1(10), 160-165.

Bałdowska-Witos, P., Kruszelnicka, W., Kasner, R., Tomporowski, A., Flizikowski, J., Kłos, Z., Piotrowska, K., Markowska, K., 2020. Application of LCA method for assessment of environmental impacts of a polylactide (PLA) bottle shaping, Polymers, 12(2).

Bałdowska-Witos, P., Piotrowska, K., Kruszelnicka, W., Błaszczak, M., Tomporowski, A., Opielak, M., Kasner, R., Flizikowski, J., 2020. Managing the uncertainty and accuracy of life cycle assessment results for the process of beverage bottle moulding, Polymers, 12(6).

Czaplicka-Kolarz, K., Burchart-Korol, D., Korol, J., 2013. Application of life cycle assessment and exergy to environmental evaluation of selected polymers, Polimery, 58(7-8), 605-609. 
Doerffer, K., Bałdowska-Witos, P., Pysz, M., Doerffer, P., Tomporowski, A., 2021. Manufacturing and Recycling Impact on Environmental Life Cycle Assessment of Innovative Wind Power Plant Part 1/2, Materials, 14, 220.

Fuc, P., Kurczewski, P., Lewandowska, A., Nowak, E., Selech, J., Ziolkowski, A., 2016. An environmental life cycle assessment of forklift operation: a well-to-wheel analysis, Int. J. Life Cycle Assess, 21(10), 1438-1451.

Jian, L. H., Baoquan, C., Weisheng, L., Jun, X., Junjie, W., Weicheng, B., Zhiping, G., 2020. Carbon emission reduction in prefabrication construction during materialization stage: A BIM-based life-cycle assessment approach, Science of The Total Environment, 723.

Klimecka-Tatar, D., 2017. Value stream mapping as lean production tool to improve the production process organization - case study in packaging manufacturing. Production Engineering Archives, 17, 40-44, DOI: 10.30657/pea.2017.17.09

Kojnoková, T., Markovičová, L., Nový, F., 2020. The changes of LD-PE films after exposure in different media. Production Engineering Archives, 26(4), 185-189, DOI: 10.30657/pea.2020.26.32

Kruszelnicka, W., Kasner, R., Baldowska-Witos, P., Flizikowski, J., Tomporowski, A., 2020. The Integrated Energy Consumption Index for Energy Biomass Grinding Technology Assessment, Energies, 13(6).

Kuczenski, B., Geyer, R., 2011. Life Cycle Assessment of Polyethylene Terephthalate (PET). Beverage Bottles Consumed in the State of California, Drrr-2014-1487.

Lewandowska, A., 2011. Environmental life cycle assessment as a tool for identification and assessment of environmental aspects in environmental management systems (EMS) part 1: Methodology, Int. J. Life Cycle Assess, 16(2), 178-186.

Madival, S., Auras, R., Singh, S.P., Narayan, R., 2009. Assessment of the environmental profile of PLA, PET and PS clamshell containers using LCA methodology, Journal of Cleaner Production, 17, 1183-1194.

Piasecka, I., Bałdowska-Witos, P., Piotrowska, K., Tomporowski, A., 2020. Ecoenergetical life cycle assessment of materials and components of photovoltaic power plant, Energies, 16(3).

Rosak-Szyrocka, J., Abbase, A. A., 2020. Quality management and safety of food in HACCP system aspect. Production Engineering Archives, 26(2), 50-53, DOI: 10.30657/pea.2020.26.11

Shen, L., Worrell, E., Kumar Patel, M., 2010. Open-loop recycling: A LCA case study of PET bottle-to-fibre recycling, Resources Conservation and Recycling, 55(1), 3452.

Ullah, M., Khan, A. M., Nawaz, R., Akhtar, R., 2016. Process Improvement for PET Bottles Manufacturing Company Using Six Sigma Approach, Pakistan, Technical Journal, University of Engineering and Technology (UET), Taxila, 21(2).

Wilczarska, J., 2012. Efektywność i bezpieczeństwo użytkowania maszyn. Inż. i Ap. Chem. 2, 41-43. 